\title{
Analysis of Factors that Influence the Participation of Women of Childbearing Age in the Examination of Visual Acetic Acid Inspection (IVA) in Kanor Public Health Center, Bojonegoro Regency
}

\author{
Agung Cahyono $^{1}$, Nurwijayanti ${ }^{2}$, \\ Ratna Wardani ${ }^{3}$ \\ ${ }^{1}$ Master Program of Public \\ Health, IIK STRADA Indonesia \\ ${ }^{2}$ IIK STRADA Indonesia \\ ${ }^{3}$ IIK STRADA Indonesia \\ Email: \\ chyo.hajj12@gmail.com.com
}

\begin{abstract}
Cervical cancer is the most common case and almost $70 \%$ of it is found in an advanced stage condition (> stage IIB). Screening implementation is still low, which is $<5 \%$. In fact, the ideal screening implementation is $80 \%$. Actually, early-stage cervical cancer can be diagnosed by performing a cytological examination through IVA. Nearly $50 \%$ of people with cervical cancer do not do IVA. The purpose of this study was to determine the effect of health services, maternal motivation, level of knowledge, and husband's support for the participation of women of childbearing age in the IVA examination at the Kanor Health Center. This research method is analytic research with cross sectional approach. The study population was all women of childbearing age between 30 and 50 years in the Kanor Health Center area. Proportional random sampling technique with a total sample of 300 people. Data analysis techniques using multiple logistic regression. The results showed that the variables that influenced participation in the IVA examination were health services $(\mathrm{p}=0,000$ and beta $=0.050)$ and maternal motivation $\quad(p=0,000$ and beta 0.037). While the variables that did not affect the participation of IVA examination were knowledge and husband support. The results of data analysis showed that the most dominant variable affecting the participation of women of childbearing age in the IVA examination was health services with a $p$ value of 0.000 and an Odd Ratio of 0.050 , which means that good health services will have a greater influence on the participation of women of childbearing age in IVA examinations by 0.050 times compared to poor health services. Therefore, it is necessary to have health promoter staff to provide information about health services as well as education or health education about early detection of cervical cancer through examinations.
\end{abstract}

Keywords: Health services, mother's motivation, health promoter

Copyright $\odot 2021$ IIK STRADA Indonesia
All right reserved.

Copyright $\odot 2021$ IIK STRADA Indonesia
All right reserved.
Accepted : April $6^{\text {th }} 2021$

Published : May $20^{\text {th }} 2021$

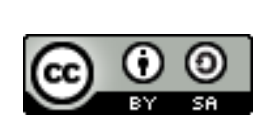

This is an open-acces article distributed under the terms of the Creative Commons Attribution-ShareAlike 4.0 International License.

\section{INTRODUCTION}

Cervical cancer is the most common case and almost $70 \%$ of it is found in an advanced stage condition (> stage IIB). This is because the screening implementation is still low, which is $<5 \%$. In fact, the ideal screening implementation is $80 \%$. Actually, early-stage cervical cancer can 
be diagnosed by performing a cytological examination through IVA. Nearly $50 \%$ of cervical cancer sufferers apparently do not do IVA. The high mortality rate due to cervical cancer in Indonesia is caused by $95 \%$ of women not undergoing early examinations, causing delays in diagnosis of cervical cancer and decreasing women's life expectancy. This is based on the fact that more than $50 \%$ of women diagnosed with cancer have never been screened.

Visual Acetate Acid Inspection (IVA) is one method for screening or early detection of cervical cancer. Since 2018 all Bojonegoro District Health Centers have provided IVA services, but as of 20119 IVA coverage in Bojonegoro District was still low at 2.25\% while the expected target was $10 \%$ of women aged $30-50$ years. The low coverage of IVA as early detection of cervical cancer shows that participation in IVA examination is still low, therefore this study was conducted to find out the factors that influence the participation of women of childbearing age in IVA examination.

The purpose of this study in general is to determine the effect of health services, mother's motivation, level of knowledge, husband's support for the participation of Fertile Women in the examination of Visual Acetate Acid Inspection (IVA). The specific objectives of the study are 1) identifying health services in IVA examinations, 2) identifying maternal motivation in IVA examinations, 3) identifying the level of knowledge of mothers about IVA examinations, 4) identifying husband support in IVA examinations, 5) identifying the level of participation of women of childbearing age couples in IVA examinations, 6) analyzing the influence of health services on the level of participation of women of childbearing age on IVA examinations, 7) analyzing the influence of maternal motivation on the participation of women of childbearing age couples on IVA examinations, 8) analyzing the influence of knowledge mothers to the level of participation of women of childbearing age couples to IVA examination, 9) analyze the influence of husband support on the level of participation of women of childbearing age couples to IVA examination. The theory used as the basis of this research is the theory of early detection of cervical cancer according to the Indonesian Ministry of Health (2015), service dimensions according to Bustami (2011), motivation theory according to Taufik (2007), the concept of knowledge according to Notoadmojo (2007) and the concept of husband support according Sheridan and Radmacher (1992).

\section{MATERIALS AND METHODS}

This research method is analytical research with cross-sectional design. The location of the study was in the Bojonegoro District Health Center Kanor. The study population was all women of childbearing age between 30 and 50 years who were in the work area of the Kanor Health Center. The sampling technique used was proportional random sampling with a total sample of 300 people. Data analysis techniques using multiple logistic regression. Data collection techniques using questionnaire forms. Data analysis used a multiple logistic regression statistical test. SK Ethical Clearence no : 1891/KEPK/IX/2020.

\section{RESULTS}

The age characteristics of the respondents showed that almost half of the respondents were in the 41-45 age range as many as 124 respondents (41.3\%), while the educational characteristics of the respondents indicated that almost all respondents had high school education as many as 228 people $(76 \%)$. The occupational characteristics of the respondents indicate that most of the respondents are housewives. As many as 164 people (54.6\%).

The characteristics of the respondents' assumptions about health services at the Kanor Health Center showed that almost all respondents thought that the health services at the Kanor Public Health Center were in the good category as many as 264 people (88\%) (table 1). The characteristics of the respondents' motivation indicated that most of the respondents in the Kanor Health Center had a high category of motivation as many as 226 people (75.3\%) (table 2).

The characteristics of the respondent's knowledge indicate that almost all respondents in the Kanor Health Center have high category knowledge of 237 people (79\%) (table 3). Characteristics of respondents to husband's support showed that almost all respondents in the Kanor Health Center had husband support with a high category of 241 people (80.3\%) (table 4). Characteristics of respondents to participation in the IVA examination showed that almost all respondents in the Kanor Health Center had participated in the IVA examination with the category of having participated as many as 266 people (88.7\%) (table 5).

Almost all respondents with high school education have high category knowledge as many as 178 respondents $(79.1 \%$ ) (table 6), while respondents with high knowledge almost all have an 
assumption that health services at the Kanor Public Health Center are in the good category as many as 189 people $(79.7 \%$ ) (table 7). Almost all respondents with high knowledge also have high motivation category as many as 199 respondents (83.9\%) (table 8). Almost all respondents with high husband's support had a high motivation category as many as 203 respondents $(84.2 \%$ ) (table 9). Almost all of the respondents who participated in the IVA examination showed that they had participated in the IVA examination as many as 117 people (94.4\%) (table 10). Almost all respondents who work as housewives indicated that 144 people had participated in IVA examinations (87.8\%) (table 11). Nearly all of the respondents who stated that health services were good with participation in the IVA examination showed that as many as 209 people (97.6\%) had participated in the category (97.6\%) (table 12).

Almost all respondents with high motivation participated in IVA examinations as many as 221 people (97.8\%) (table 13). All respondents with high knowledge had participated in the IVA examination category had participated in as many as 237 people (100\%) (table 14) and also all respondents with high husband support had participated in the IVA examination category had participated as many as 241 people (100\%) (table 14 ).

Based on the results of the analysis of the results of the logistic regression statistical test on health services, motivation, knowledge and support of husbands for participation in the IVA examination of respondents, it can be seen (table 15) that health services for participation in IVA examinations show a significant value (p-value) of $0.000<0.05$. then $\mathrm{H} 0$ is rejected and $\mathrm{H} 1$ is accepted, so it is concluded that there is an effect of health services on the participation of women of childbearing age in IVA examinations at the Kanor Health Center, Bojonegoro Regency. With good health services (0.050), the greater the effect will be on the participation of women of childbearing age in IVA examinations by 0.050 times compared to poor health services, while the motivation to participate in IVA examinations shows a significant value $(p=0.000<0.05), \mathrm{H} 0$ is rejected and $\mathrm{H} 1$ is accepted, so it can be concluded that there is a motivational effect on the participation of women of childbearing age in IVA examinations at the Kanor Health Center, Bojonegoro Regency. With high maternal motivation (0.037), the greater the effect on the participation of women of childbearing age in IVA examinations by 0.037 times compared to those who received low motivation. The effect of the level of knowledge on participation in the IVA examination shows a significant value ( $p=0.994>0.05)$, so H0 is accepted and H1 is rejected, so it is concluded that there is no influence of knowledge on the participation of women of childbearing age in IVA examinations at the Kanor Health Center, Bojonegoro Regency.

High knowledge (0.000) does not have a big effect on the participation of women of childbearing age in IVA examinations by 0.000 times compared to those who have low motivation. health services, motivation, knowledge and support of husbands by participating in IVA examinations. The effect of husband's support on participation in examination IV shows a significant value ( $p=0.992>0.05)$, so $\mathrm{H} 0$ is accepted and H1 is rejected, so it can be concluded that there is no influence of motivation on the participation of women of childbearing age in IVA examinations at the Kanor Health Center, Bojonegoro Regency. High husband support (0.000) does not have a big effect on the participation of women of childbearing age in IVA examinations by 0.000 times compared to those with low motivation.

The tabulation of the research results is shown in table 1 to table 14 below;

Table 1 Distribution of the frequency of respondents based on health services

\begin{tabular}{ccc}
\hline Criteria & Frequency & Percentage (\%) \\
\hline Good & 264 & 88,0 \\
Non Good & 36 & 12,0 \\
\hline Total & 300 & 100 \\
\hline
\end{tabular}

Table 2 Distribution of respondent frequency based on Mother's Motivation

\begin{tabular}{ccc}
\hline Criteria & Frequency & Percentage (\%) \\
\hline Tinggi & 226 & 75,3 \\
Rendah & 74 & 24,7 \\
\hline Total & 300 & 100 \\
\hline
\end{tabular}


Table 3 Frequency distribution of respondents based on maternal knowledge

\begin{tabular}{rcc}
\hline Criteria & Frequency & Percentage (\%) \\
\hline Tinggi & 237 & 79,0 \\
Rendah & 63 & 21 \\
\hline Total & 300 & 100 \\
\hline
\end{tabular}

Table 4 Frequency distribution of respondents based on husband's support

\begin{tabular}{ccc}
\hline Criteria & Frequency & Percentage $(\%)$ \\
\hline High & 241 & 80,3 \\
Low & 59 & 19,7 \\
Total & 300 & 100 \\
\hline
\end{tabular}

Table 5 Frequency distribution of respondents based on participation in the IVA examination

\begin{tabular}{ccc}
\hline Criteria & Frequency & Percentage ( \% ) \\
\hline Pernah & 266 & 88,7 \\
Tidak pernah & 34 & 11,3 \\
\hline Total & 300 & 100 \\
\hline
\end{tabular}

Tabel 6 Crosstabulation of education with respondent's knowledge

\begin{tabular}{lcccccc}
\hline \multirow{2}{*}{ Education } & \multicolumn{4}{c}{ Knowledge } & \multicolumn{2}{c}{ Total } \\
\cline { 2 - 6 } & \multicolumn{2}{c}{ Low } & $\mathrm{N}$ & \multicolumn{2}{c}{ High } & \multicolumn{2}{c}{} \\
\cline { 2 - 6 } & $\mathrm{N}$ & $\%$ & $\mathrm{~N}$ & $\%$ & $\mathrm{~N}$ & $\%$ \\
\hline SMP & 4 & 30,8 & 9 & 69,2 & 13 & 4,3 \\
SMU & 50 & 21,9 & 178 & 79,1 & 228 & 76,0 \\
Diploma/Sarjana & 9 & 15,3 & 50 & 84,7 & 59 & 19,7 \\
\hline Total & 63 & 21,0 & 237 & 79,0 & 300 & 100 \\
\hline
\end{tabular}

Table 7 Crosstabulation of respondent's knowledge with health services

\begin{tabular}{lccccccc}
\hline \multirow{2}{*}{ Knowledge } & \multicolumn{4}{c}{ Health Service } & \multicolumn{2}{c}{ Total } \\
\cline { 2 - 5 } & \multicolumn{2}{c}{ Not Good } & \multicolumn{2}{c}{ Good } & & \multirow{2}{*}{ N } \\
\cline { 2 - 6 } & $\mathrm{N}$ & $\%$ & $\mathrm{~N}$ & $\%$ & $\mathrm{~N}$ & $\%$ \\
\hline Rendah & 33 & 52,4 & 30 & 47,6 & 63 & 21,0 \\
High & 48 & 20,3 & 189 & 79,7 & 237 & 79,0 \\
\hline Total & 81 & 27,0 & 219 & 73,0 & 300 & 100 \\
\hline
\end{tabular}

Tabel 8 Cross tabulation of knowledge and motivation of respondents

\begin{tabular}{|c|c|c|c|c|c|c|}
\hline \multirow{3}{*}{ Knowledge } & \multicolumn{4}{|c|}{ Motivation } & \multirow{2}{*}{\multicolumn{2}{|c|}{ Total }} \\
\hline & \multicolumn{2}{|c|}{ Low } & \multicolumn{2}{|c|}{ High } & & \\
\hline & $\mathrm{N}$ & $\%$ & $\mathrm{~N}$ & $\%$ & $\mathrm{~N}$ & $\%$ \\
\hline Low & 36 & 57,1 & 27 & 42,8 & 63 & 21,0 \\
\hline High & 38 & 16,0 & 199 & 83,9 & 237 & 79,0 \\
\hline Total & 74 & 24,7 & 226 & 75,3 & 300 & 100 \\
\hline
\end{tabular}


Tabel 9 Tabulasi silang dukungan suami dengan motivasi responden

\begin{tabular}{lcccccc}
\hline \multirow{2}{*}{$\begin{array}{c}\text { Husband's } \\
\text { Support }\end{array}$} & \multicolumn{4}{c}{ Low } & \multicolumn{3}{c}{ High } & \multicolumn{2}{c}{ Total } \\
\cline { 2 - 6 } \cline { 2 - 7 } & $\mathrm{N}$ & $\%$ & $\mathrm{~N}$ & $\%$ & $\mathrm{~N}$ & $\%$ \\
\hline Low & 36 & 61.1 & 23 & 38,9 & 59 & 19,7 \\
High & 38 & 15,8 & 203 & 84,2 & 241 & 80,3 \\
\hline Total & 74 & 24,6 & 226 & 75,3 & 300 & 100 \\
\hline
\end{tabular}

Tabel 10 Cross tabulation of age with participation in IVA examinations

\begin{tabular}{lcccccc}
\hline \multirow{2}{*}{ Age } & \multicolumn{3}{c}{ Participation in the IVA examination } & \multicolumn{2}{c}{ Total } \\
\cline { 2 - 5 } & \multicolumn{2}{c}{ Never } & \multicolumn{2}{c}{ Ever } & \multicolumn{2}{c}{} \\
\cline { 2 - 5 } & $\mathrm{N}$ & $\%$ & $\mathrm{~N}$ & $\%$ & $\mathrm{~N}$ & $\%$ \\
\hline 30-35 year & 6 & 12,5 & 42 & 87,5 & 48 & 16,0 \\
36-40 year & 17 & 17,3 & 81 & 82,7 & 98 & 32,7 \\
41-45 year & 7 & 5,6 & 117 & 94,4 & 124 & 41,3 \\
46-50 year & 4 & 13,3 & 26 & 86,7 & 30 & 1,0 \\
\hline Total & 34 & 11,3 & 266 & 88,6 & 300 & 100 \\
\hline
\end{tabular}

Tabel 11 Cross tabulation of work with participation in IVA examinations

\begin{tabular}{|c|c|c|c|c|c|c|}
\hline \multirow{3}{*}{ Profession } & \multicolumn{4}{|c|}{ Participation in the IVA examination } & \multirow{2}{*}{\multicolumn{2}{|c|}{ Total }} \\
\hline & \multicolumn{2}{|c|}{ Never } & \multicolumn{2}{|c|}{ Ever } & & \\
\hline & $\mathrm{N}$ & $\%$ & $\mathrm{~N}$ & $\%$ & $\mathrm{~N}$ & $\%$ \\
\hline Ibu Rumah & 20 & 12,1 & 144 & 87,8 & 164 & 54,7 \\
\hline Tangga & & & & & & \\
\hline Swasta & 11 & 12,7 & 75 & 87,2 & 86 & 28,7 \\
\hline Wiraswasta & 3 & 6,0 & 47 & 94 & 50 & 16,6 \\
\hline Total & 34 & 11,3 & 266 & 88,7 & 300 & 100 \\
\hline
\end{tabular}

Tabel 12 Crosstabulation of work with participation in the respondent's IVA examination

\begin{tabular}{lcccccc}
\hline \multirow{2}{*}{ Health Service } & \multicolumn{3}{c}{ Participation in the IVA examination } & \multicolumn{2}{c}{ Total } \\
\cline { 2 - 6 } & \multicolumn{2}{c}{ Never } & \multicolumn{3}{c}{ Ever } & \multicolumn{2}{c}{} \\
\cline { 2 - 6 } & $\mathrm{N}$ & $\%$ & $\mathrm{~N}$ & $\%$ & $\mathrm{~N}$ & $\%$ \\
\hline Good & 5 & 2,3 & 214 & 97,6 & 219 & 71,3 \\
Not Good & 29 & 33,7 & 52 & 66,3 & 86 & 28,7 \\
\hline Total & 34 & 11,3 & 266 & 96,3 & 300 & 100 \\
\hline
\end{tabular}

Tabel 13 Cross tabulation of motivation with participation in IVA examinations

\begin{tabular}{|c|c|c|c|c|c|c|}
\hline \multirow{3}{*}{ Motivation } & \multicolumn{4}{|c|}{ Participation in the IVA examination } & \multirow{2}{*}{\multicolumn{2}{|c|}{ Total }} \\
\hline & & & & & & \\
\hline & $\mathrm{N}$ & $\%$ & $\mathrm{~N}$ & $\%$ & $\mathrm{~N}$ & $\%$ \\
\hline$\overline{\text { High }}$ & 5 & 2,2 & 221 & 97,8 & 226 & 75,3 \\
\hline Low & 29 & 39,2 & 45 & 60,8 & 74 & 24,7 \\
\hline Total & 34 & 11,7 & 265 & 88,3 & 300 & 100 \\
\hline
\end{tabular}

Tabel 14 Cross tabulation of knowledge with participation in the IVA examination

\begin{tabular}{|c|c|c|c|c|c|c|}
\hline \multirow{3}{*}{ Knowledge } & \multicolumn{4}{|c|}{ Participation in the IVA examination } & \multirow{2}{*}{\multicolumn{2}{|c|}{ Total }} \\
\hline & \multicolumn{2}{|c|}{ Never } & \multicolumn{2}{|c|}{ Ever } & & \\
\hline & $\mathrm{N}$ & $\%$ & $\mathrm{~N}$ & $\%$ & $\mathrm{~N}$ & $\%$ \\
\hline High & 0 & 0,0 & 237 & 100 & 237 & 79 \\
\hline Low & 34 & 12,8 & 29 & 46,1 & 63 & 21 \\
\hline Total & 34 & 12,8 & 266 & 88,7 & 300 & 100 \\
\hline
\end{tabular}


Tabel 15 Cross tabulation of husband's support with participation in IVA examinations

\begin{tabular}{|c|c|c|c|c|c|c|}
\hline \multirow{3}{*}{ Husband's } & \multicolumn{4}{|c|}{ Participation in the IVA examination } & \multirow{2}{*}{\multicolumn{2}{|c|}{ Total }} \\
\hline & \multicolumn{2}{|c|}{ Never } & \multicolumn{2}{|c|}{ Ever } & & \\
\hline & $\mathrm{N}$ & $\%$ & $\mathrm{~N}$ & $\%$ & $\mathrm{~N}$ & $\%$ \\
\hline$\overline{\text { High }}$ & 0 & 0,0 & 241 & 100 & 241 & 80,3 \\
\hline Low & 34 & 57,6 & 25 & 42,4 & 59 & 19,7 \\
\hline Total & 34 & 12,8 & 266 & 88,7 & 300 & 100 \\
\hline
\end{tabular}

Tabel 16 The results of the statistical test of health services, motivation, knowledge and husband's support by participating in the IVA examination

\begin{tabular}{lcccc}
\hline \multicolumn{1}{c}{ Variabel } & Sig. Simultan & R. Square & Sig. partial & Exp. (B ) \\
\hline Health Service & & & 0.000 & 0.050 \\
Motivaton & 0.000 & 0.578 & 0.000 & 0.037 \\
Knowledge & & $\cdot$ & 0,994 & 0.000 \\
Husban'd Support & & 0.992 & 0.000 \\
\hline
\end{tabular}

\section{DISCUSSION}

The identification of health services at the Kanor Health Center shows a good category. The health services for the participation in the IVA examination show that the better the health service, the greater the participation in the IVA examination. Almost all respondents who have participated in services stated that health services are good (97.6\%). Most of the respondents (64\%) stated that the services provided on the tangible dimension were in the good category, and almost half of the respondents $(31 \%)$ stated that very good. However, a small proportion of respondents $(5 \%)$ stated that the health services at the Kanor Public Health Center are not good, this is inseparable from the indicators that affect this dimension. The physical building of the Kanor Public Health Center was renovated in 2019, so that the arrangement is in accordance with the Minister of Health Regulation No. 75 of 2014. Assessment of employee appearance is also in the good category, this is indicated by the appearance of service employees at the Kanor Public Health Center who are neatly dressed and wearing clothes according to the stipulated provisions. Furthermore, in the use of technology, the results obtained are good, this is related to the use of computers in administrative processes, and other medical devices that have taken advantage of technological advances. However, the equipment and equipment facilities are not yet considered good and must be considered in improving the quality of health services for pregnant and childbirth mothers, this is in accordance with the results obtained that the equipment and equipment at the Kanor Health Center are still in the bad category, such as the absence of equipment. ultrasound examination. In the reliability dimension, it can be seen that most of the respondents (52\%) stated that the service on the reliability dimension was good, and almost half of the respondents $(33 \%)$ stated that the services provided were very good. A small proportion of respondents $(15 \%)$ stated that they were not good.

Therefore, from the data from the short interview results and the table data above, it can be stated that the service in the dimension of reliability is good, which is shown by the officers who are able to communicate clearly for the purpose of performing the IVA examination. The skills and abilities of service personnel are also in good category. This can be seen through the assessment indicators of good examination accuracy, accuracy in administering good drugs due to the presence of special drug administrators, clarity of good service standards, good and correct service schedules. In terms of the accuracy of the examination, it can be seen that the officers are skilled and thorough, because there are several officers of the Kanor Public Health Center who have conducted special training to provide IVA examination services. In the Responsiveness dimension, it can be seen that most of the respondents $(59 \%)$ answered that the service in the responsiveness dimension was good and almost half of the respondents (30\%) said it was very good. The responsiveness of officers in resolving complaints is included in the good category, this is because the responsiveness of the response given to service user complaints by officers is responsive and straightforward, clear service procedures, information provided by officers is also good by using easy language understood by service users, providing the right diagnosis, and providing the right service according to predetermined standards. In the assurance dimension, it can be seen that most of the respondents (50\%) stated that the health services at the Kanor Health Center in the assurance dimension were 
good, and almost half of the respondents (35\%) stated that it was very good, but there was a small proportion of respondents $(15 \%)$ who stated Health services at the Kanor Health Center are not good. Thus from the data from the interview results and the table data above it can be stated that the service in the assurance dimension is good, this is shown by the officers being on time in carrying out the service, then the guaranteed costs in services such as service users can use the BPJS card, further guaranteeing the legality of the service and the providing officer. services that have been polite and courteous in providing services to service users according to applicable norms. In the Empathy dimension, it can be seen that most of the respondents (53\%) stated that the service in the empathy dimension was good, and almost half of the respondents (35\%) said it was very good. However, a small proportion of respondents (13\%) stated that they were not good. The level of friendliness and patience which is included in the good category in understanding patients, officers do not differentiate between patients who will be served, this is evidenced by no patient who is devoted to getting service. Service users will get service if they have done things according to predetermined service procedures. Thus, the assessment of each dimension of service quality is in the good category. It can be measured by the quality of IVA examination health services at the Kanor Health Center, Bojonegoro Regency as a whole based on the dimensions of Tangible, Reliability, Responsiveness, Assurance, and Empathy.

Motivation identification at the Kanor Health Center shows a high category (75.3\%). The motivation by participating in the IVA examination also shows that the higher the motivation, the greater the participation in the IVA examination. Of the 226 respondents with high motivation, almost all of the respondents who participated in the IVA examination category had participated as many as 221 respondents $(97.8 \%)$, while those who had never participated in the IVA examination were only 5 respondents $(2.4 \%)$. The answer of the respondent with the highest score $(84.5 \%)$ to the question item on the variable of mother's motivation was "reproductive health, especially the health of sexual organs, is very important for women" and "every woman of childbearing age has the right to get reproductive health". And this illustrates that the mother has realized the importance of participating in IVA testing. While the responses of respondents in the low category $(48.3 \%)$ to the question of maternal motivation variables included "I received information about examinations about IVA examinations through electronic media (TV, magazines)" and "Apart from electronic media, I often read books on early detection. cervical cancer and those related to IVA examinations. "So it can be described that respondents have not responded to information about health and mothers feel they have never received information about IVA examinations, after confirmation by Public Health Center officers that in coaching in the villages the schedule of activities has not been completed and is new In several villages, it is not entirely up to the mother to provide information on early detection of cervical cancer to get information about early detection of cervical cancer. This is in accordance with the statement from Notoatmodjo (2007) that motivation has 3 (three) functions, namely encouraging humans to act, so as a driving or motor that releases energy. Motivation in this case is the driving force of each activity to be carried out, determining the direction of action, namely towards the goal to be achieved. Thus motivation can provide direction and activities that must be carried out in accordance with the formulation of pre-planned goals and select actions, namely determining what actions must be carried out in harmony in order to achieve the goal, by setting aside actions that are not useful for that goal. The choice of actions that have been determined or carried out will give you high self-confidence because you have carried out the selection process. Because most mothers consider the IVA examination important for early detection of cervical cancer. This situation also needs to be supported by coaching and socialization regarding IVA examinations from health workers in the village, namely village midwives and village health cadres to PKK mothers, arisan groups and mothers who deliver their children in PAUD. Meanwhile, the mother's low motivation is due to lack of information and fear of IVA examination. When asked by cadres and health workers he always avoided, therefore there needs to be cross-sector cooperation, especially the District Leadership Forum (FORPIMKA).

The identification of the level of knowledge at the Kanor Health Center shows that almost all respondents $(72.6 \%)$ stated that the mother's knowledge was in a high category. The respondent's response with the highest score $(87.7 \%)$ to the knowledge variable question item was "the husband needs to be involved in the IVA examination". And this illustrates that the mother knows that the role of her husband in the IVA examination is very important. While the responses of respondents in the low category $(37.3 \%)$ to the question of knowledge variables included "vaginal discharge that is getting longer and smells bad, is an early symptom of cervical cancer". From this statement, it can be illustrated that respondents do not know the information about cervical cancer symptoms and information about IVA examinations. So we need counseling or provide information about cervical cancer to mothers as well as information about early detection of cervical cancer. The results of this 
study support the research of Suarniti, et al. (2013) showing that there is a difference in knowledge between women who underwent an IVA examination and those who did not undergo an IVA examination, where the knowledge of women who underwent an IVA test was higher than those of women who did not undergo an IVA examination, this shows that the decision making of WUS to undergo IVA examination is influenced by the knowledge they have. Likewise, the research of Ningrum, et al. 2012 in Banyumas Regency in looking for factors that influence mother's motivation to perform IVA examinations, where the results obtained are one of the influencing factors is knowledge with a value of $40 \%$ of the 38 total samples studied. The above is in accordance with the theory described by Notoatmodjo (2007), which states that knowledge or cognitive is a very important domain for the formation of someone's over behavior, and according to him there are several factors that influence behavior, including age, education, work environment. , and experience. Experience and education are factors that affect a person's knowledge (Notoatmodjo, 2007). Experience can be obtained from the experiences of yourself and others. The experience that has been obtained can broaden a person's knowledge, while education can bring someone's insight or knowledge that will influence their behavior. In general, someone with a higher education will have more knowledge than someone with a lower level of education.

The identification of husband's support shows that almost all respondents $(72.6 \%)$ state that their husband's support is in a high category with an average value. The respondent's response with the highest score $(87.7 \%)$ to the knowledge variable question item was "the husband needs to be involved in the IVA examination". And this illustrates that the mother knows that the role of her husband in the IVA examination is very important. While the responses of respondents in the low category (37.3\%) to the question of knowledge variables included "vaginal discharge that is getting longer and smells bad, is an early symptom of cervical cancer". From this statement, it can be illustrated that respondents do not know the information about cervical cancer symptoms and information about IVA examinations. So we need counseling or provide information about cervical cancer to mothers as well as information about early detection of cervical cancer. Sheridan and Radmacher (1992), Sarafino (1998) and Taylor (1999) divide social support into five forms, namely instrumental support, informational support, emotional support, self-esteem support and group support. Instrument support is the provision of material that can provide direct assistance such as loan money, providing goods, food and services. This form of support can reduce stress because individuals can immediately solve problems related to the material. Instrumental support is needed, especially in overcoming problems. Informational support involves providing information, suggestions or feedback about individual situations and conditions. This type of information can help individuals identify and solve problems more easily. Emotional support makes individuals feel comfortable, confident, cared for and loved by social support sources so that individuals can deal with problems better. Women who get good social support (support from their partners, family, friends, or community leaders) tend to do early detection of cervical cancer. If a woman does not have a close group, it will indirectly affect the woman's behavior. The husband is the closest person to the mother in interacting and making decisions. This support is very important in dealing with situations that are considered uncontrollable. Support for self-esteem can be in the form of positive rewards for individuals, encouragement, approval of individual opinions and positive comparisons with other individuals. This form of support helps individuals in building self-esteem and competence and the form of support in groups can make individuals feel members of a group who share common interests and social activities with them. That way individuals will feel they have the same friends. To increase husband's support, it can be done by giving brochures / leaflets to female women so that later they can be given to husbands and making WUS husbands the importance of early detection of cervical cancer as a target for counseling on the IVA method.

From the identification of the participation of couples of childbearing age above, it shows that the percentage of respondents who have participated in the IVA examination is $88.7 \%$ of the total respondents. This shows that almost all of the respondents who have had an IVA examination are more than the respondents who have never performed an IVA examination. In a brief interview with respondents who had participated in the IVA examination, it was stated that the examination was carried out at the Kanor Health Center as many as 243 respondents, while 23 respondents did it at the Sumberejo Regional Hospital, Bojonegoro Regency. There are 34 respondents who have never participated in IVA examinations, they stated that they did not know the information about IVA examinations carried out at Public Health Center or carried out at hospitals. According to Supriyanto \& Ernawati (2010) a need is something that is fundamental in nature needed to meet human problems, while a desire is a need that has become an impetus (desire: desire to fulfill a need) to be resolved when they are directed to a specific specific goal / object, which enables satisfy a need. Mothers who need IVA checkups feel that all health services are important and beneficial to improve women's 
health. Most of the mothers who said they did not need it because they had never heard information about IVA services and felt sure that they did not have cervical cancer. Not all mothers who need IVA services are motivated to undergo examinations, most of the reason is a feeling of shame or embarrassment when their reproductive organs have to be seen by health workers. Positive maternal perceptions about IVA services are associated with IVA examination visits (Pertiwi, 2015). Mothers who have an unsupportive attitude about IVA services are 2.04 times more likely not to undergo IVA examinations compared to mothers who are supportive of IVA examinations (Sidabutar, 2013). Mothers who realize that cervical cancer is a dangerous disease for women will make IVA examinations as an early detection of cervical cancer into their needs. Mothers who feel a need will be encouraged to fulfill their needs in the form of a desire to have an IVA check. With the participation of early IVA examinations, it is a form of early detection of cervical cancer. The earlier the IVA test is performed, the faster it will be to find abnormal cells such as cervical cancer and the more optimal the treatment and cure for cervical cancer will be.

Analysis of the effect of health services on the participation rate of fertile age couples on IVA examination is indicated by the results of the statistical test of this study which obtained a significant value of 0.000 , so health services have a significant effect on the participation of women of childbearing age in IVA examinations. With good health services (Exp. $(B)=0.050)$, the greater the effect on the participation of women of childbearing age in IVA examinations by 0.050 times compared to poor health services. Almost all of the respondents who had participated in the IVA examination stated that the Kanor Health Center health service was in a good category (97.6\%). Health services at the Kanor Health Center from 2012 to 2016 have received ISO certificates and in 2016 also received major accreditation. According to Fitzsimmons and Fitzsimmons (2009) service quality consists of five influencing aspects, namely: reliability which is marked by the provision of appropriate and correct services, Tangibles which is marked by the provision which marks human resources and other resources, Responsiveness is marked by the desire to serve consumers quickly, Assurance which is marked by the level of attention to ethics and morals in providing services, Empaty which is marked by the level of willingness to know the wants and needs of the community. The five dimensions mentioned above are known as Service Quality (ServQual). The essence of ServQual is to measure the expectations (expectations) and perceptions (reality) of the services received. Quality health services are health services that can satisfy every health service user according to the average satisfaction level of the population. Its implementation must also be in accordance with established standards and professional code of ethics. Patients tend to choose or prioritize health service quality indicators, as a basis for deciding on their level of satisfaction (Cahyadi, 2007). Good or bad quality of health services will affect the level of patient satisfaction because patients will respond and assess the quality of health services.

Analysis of the influence of mother's motivation on the participation of fertile-aged couples on IVA examination shows the results of statistical tests with a significant value of 0.000 , so motivation has a significant effect on the participation of women of childbearing age in the IVA examination. With high maternal motivation (Exp. $(B)=0.037)$, the greater the effect on the participation of women of childbearing age in IVA examinations by 0.037 times compared to those with low motivation. Most of the respondents $(75.3 \%)$ stated that the influence of mother's motivation on participation in IVA examinations was high. This shows that the higher the mother's motivation, the higher her participation in the IVA examination. In a short interview with respondents who had participated in the IVA examination, it was found that almost all respondents received high motivation from their families. This research was supported by research conducted by Suarniti, et al. (2013) where there was a tendency for internal and external motivation of WUS who underwent the IVA test to be higher than denagna WUS who did not undergo an IVA test. Likewise in the research of Ningrum, et al. (2012) where the mother's motivation has a role in the factors that influence the mother to perform IVA examinations as many as $49 \%$ of 95 people. This is in accordance with the statement from Notoatmodjo (2007) that motivation has 3 (three) functions, namely encouraging humans to act, so as a driving or motor that releases energy. Motivation in this case is the driving force of each activity to be carried out, determining the direction of action, namely towards the goal to be achieved. Thus motivation can provide direction and activities that must be carried out in accordance with the formulation of pre-planned goals and select actions, namely determining what actions must be carried out in harmony in order to achieve the goal, by setting aside actions that are not useful for that goal. The choice of actions that have been determined or carried out will give you high self-confidence because you have carried out the selection process. In this pluralistic society, mothers' motivation is also influenced by the surrounding environment in making decisions to participate in IVA examinations. The higher the motivation given, the stronger the courage and enthusiasm to participate in the IVA examination. 
Analysis of the influence of maternal knowledge on the participation rate of fertile age couples on IVA examinations. Showing the results of a statistical test with a significant value of 0.994, knowledge does not have a significant effect on the participation of women of childbearing age in the IVA examination. With the Odd Ratio value of the knowledge variable of 0.000 , it means that knowledge does not have a big effect on the participation of women of childbearing age in the IVA examination by 0.000 times compared to low knowledge. Almost all respondents (79\%) indicated that the mother's level of knowledge about participation in the IVA examination was high. Respondents who have participated in the IVA examination show that almost all respondents have high knowledge at high school level. This shows that the higher the mother's knowledge, the easier it is for education or health education, especially about IVA examinations. In a brief interview with respondents who have participated in an IVA examination, they stated that they participated in an IVA examination because they often received information about the dangers of cervical cancer, both from print and social media. This is in accordance with the theory described by Notoatmodjo (2007), which states that knowledge or cognitive is a very important domain for the formation of one's actions (over behavior), and according to him there are several factors that influence behavior, including age, education, work environment., and experience. Experience and education are factors that affect a person's knowledge (Notoatmodjo, 2007). Experience can be obtained from the experiences of yourself and others. The experience that has been obtained can broaden a person's knowledge, while education can bring insight or knowledge of a person which will influence his behavior. In general, someone with a higher education will have more knowledge than someone with a lower level of education. So related to the IVA examination, they think it is very important to weigh the benefits for the health of mothers of fertile couples.

The analysis of the effect of husband's support on the participation rate of fertile age couples on IVA examination shows the results of statistical tests with a significant value of 0.992 , so husband's support does not have a significant effect on the participation of women of childbearing age in the IVA examination. The Odd Ratio value of the husband's support variable is 0.000 , which means that mothers with high husband support do not have a big effect on the participation of women of childbearing age in IVA examinations by 0.000 times compared to those who receive low husband support. Almost all respondents (80.3\%) showed high husband support for participating in the IVA examination. This shows that respondents who have participated in IVA examinations received high husband support. In a short interview with respondents who received high husband support, they stated that they were more enthusiastic and had the courage to participate in the IVA examination. Sheridan and Radmacher (1992), Sarafino (1998) and Taylor (1999) divide social support into five forms, namely instrumental support, informational support, emotional support, self-esteem support and group support. Instrument support is the provision of material that can provide direct assistance such as loan money, providing goods, food and services.

This form of support can reduce stress because individuals can immediately solve problems related to the material. Instrumental support is needed, especially in overcoming problems. Informational support involves providing information, suggestions or feedback about individual situations and conditions. This type of information can help individuals identify and resolve problems more easily. Emotional support makes individuals feel comfortable, confident, cared for and loved by social support sources so that individuals can deal with problems better. This support is very important in dealing with situations that are considered uncontrollable. Support for self-esteem can be in the form of positive rewards for individuals, encouragement, approval of individual opinions and positive comparisons with other individuals. In society, it is assumed that the form of husband's support helps a mother in building self-esteem, and the form of support from the community can also make individuals feel that they are members of a community group who have the same interests and social activities with her. That way individuals will feel they have the same friends. So it has an effect on increasing the coverage of maternal participation in IVA examinations.

\section{CONCLUSION}

Based on the results of the study, almost all respondents, namely 264 respondents (88\%) considered health services at the Public Health Center Kanor, Bojonegoro Regency as good categories. Almost all of the respondents who had participated in the IVA examination stated that Kanor Health Center health services were in the good category (97.6\%). Health services at the Kanor Community Health Center from 2012 to 2016 have received ISO certificates and in 2016 were also primary accredited. According to the results of the statistical test health services have a significant effect on participation in IVA examinations $(p=0,000$, exp $(B)=0.050)$. Motivation of mothers in the high category, especially from the family $(75.3 \%)$ and according to the results of statistical tests found that maternal 
motivation significantly influence participation in IVA monitoring $(p=0,000 ; \exp (B)=0.037)$. The level of husband's knowledge and support does not affect participation in the IVA examination.

The priority recommendation for increasing participation in the examination of Acetic Acid Visual Inspection (IVA) is to focus on health services both physically and in the attitude of health workers which aims to increase the trust and desire of mothers to examine IVA. That is because health services are the most dominant variable influencing the participation of women of childbearing age couples in IVA examinations and tangible is the highest component of health services to the wishes of mothers coming to check IVA to Kanor Health Center. To introduce health services at the Kanor Health Center, it is necessary to have health promoters to support promotional activities carried out by combining information or counseling with IVA examinations. Mothers who have been given information immediately offered to check in the same place, then for mothers who want to check are given interesting souvenirs, the activity is given the name "DAHSYAT IVARA".

\section{ACKNOWLEDGMENTS}

Researchers are very grateful to The Kanor Health Center who have volunteered to be involved in research activities.

\section{CONFLICT OF INTEREST}

There were no conflicts of interest before, during and after this research was completed.

\section{REFERENCES}

Anon., 2015. Jatim Darurat Kanker Serviks. Harian Pagi Surya, 6 Maret. p.1. Anonim, 2008. Keputusan Menteri Kesehatan Republik Indonesia Nomor 129 tentang Standar Pelayanan Minimal Rumah Sakit. Jakarta: Kemenkes RI.

BKKBN. 2008. Peningkatan partisipasi suami dalam kesehatan reproduksi. Jakarta: BKKBN Dinkes Kabupaten Bojonegoro, 2018. Profil Kesehatan Kabupaten Bojonegoro Tahun 2018. Bojonegoro: Dinas Kesehatan Kabupaten Bojonegoro.

Markovic, M., Kesic, V., Topic, L. \& Matejic, B., 2005. Barriers to cervical cancer screening : A qualititative study with women serbia. Elsevier, 05(001), pp.2528-35.

Mayrita, N. \& Handayani, H., 2014. Hubungan antara paritas dengan kejadian kanker serviks di Rumah Sakit Wisnu Wardhana Surabaya. Surabaya: UNUSA.

Mulyadi, 2013. Upaya Peningkatan Pemanfaatan Pelayanan Public Health Center Di Kabupaten Madiun Dengan Analisis Health Seeking Behaviour. Thesis. Surabaya: Program studi Magister Manajemen Pelayanan Kesehatan Universitas Airlangga.

Notoatmodjo, S., 2010. Ilmu perilaku Kesehatan. Jakarta: Rineke Cipta.

Nurwijaya, h.D., AndrijonoSpOG(K) \& Suhaemi, H.K.S., 2010. Cegah \& Deteksi Kanker Serviks. Elex Media Komputindo: Jakarta.

Permatasari, D., 2013. Faktor yang mempengaruhi Perilaku Wanita Dalam Melakukan Deteksi Dini Kanker Metode Papsmear di Public Health Center Pamolokan Kabupaten Sumenep. Wiraraja Medika, pp.12-20.

Pertiwi, N.d.e., 2015. Faktor-faktor yang berhubungan dengan kunjungan pemeriksaan IVA/Papsmear pada Ibu-Ibu PKK di Dusun Tajem Depok Sleman. Skripsi. YOGYAKARTA: Program Studi Bidang Pendidikan Jenjang DIV STIKES AISYIYAH.

Pusdatin, 2012. Gambaran Penyakit Tidak Menular di Rumah Sakit di Indonesia Tahun 2009 dan 2010. Buletin Jendela Data \& Informasi Kesehatan Vol 2 Semester 2, pp.1-48.

Retnaningsih, E.S..K., 2013. Akses Layanan Kesehatan. Depok: Rajagrafindo Persada.

Sankarayanan, R., Rajkumar, R. \& Arrossi, S., 2003. Determinants of participation of women in a cervical cancer visual screening trial in rural south India. International Society For Preventive Oncology, 09(006), pp.457-65.

Sidabutar, S., 2013. Analisis faktor yang mempengaruhi WUS dalam pemeriksaan IVA (Inspeksi Visual Asam Asetat) Sebagai Deteksi Dini Kanker Serviks (Studi di Dua Public Health Center di Kota Surabaya). Tesis. Surabaya: Program Magister Program Studi Kesehatan Masyarakat Universitas Airlangga Fakultas Kesehatan Masyarakat. 